\title{
Morphological and molecular characterization of some NERICA mutant lines under drought condition
}

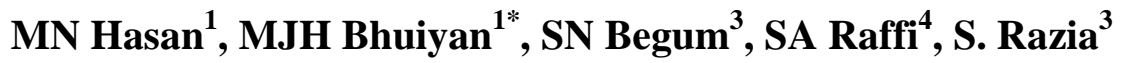

${ }^{1}$ Department of Biochemistry and Molecular Biology, Bangladesh Agricultural University, Mymensingh-2202, Bangladesh; ${ }^{3}$ Plant Breeding Division, Bangladesh Institute of Nuclear Agriculture, Mymensingh 2202, Banghadesh; ${ }^{4}$ Department of Genetics and Plant Breeding, Bangladesh Agricultural University, Mymensingh 2202, Bangladesh

\begin{abstract}
To ensure the productivity of rice in drought condition, 'NERICA' varieties of African origin has been introduced in Bangladesh and subsequently mutant lines are also developed for improving the performance further. The present study was undertaken to screen out better drought tolerant mutant lines of NERICA having other desirable traits. Thirteen NARICA mutant lines, four susceptible (BINA dhan8, BINA dhan10, BINA dhan11 and BINA dhan12) and one tolerant (BRRI dhan56) varieties were included in the experiment and selection was based on morphological and molecular characteristics. The plants were grown in pot containing 9 $\mathrm{kg}$ of soil and when they were 60 days old, drought was imposed by adding $1 \mathrm{~L}$ of distilled water at every four days interval till harvesting. The quantity of water applied to control pots was double. The results showed that important yield contributing morphological attributes like days of 50\% flowering, plant height, total number of tiller hill ${ }^{-1}$, panicle length, 100 seed weight, fresh weight of plant and dry weight of plant were significantly positively regulated due to drought in $\mathrm{N}_{10} / 300 / \mathrm{P}-2(1)-3-5, \mathrm{~N}_{1} / 250 / \mathrm{P}-6-2-7$ and $\mathrm{N}_{10} / 300 / \mathrm{P}-2(1)-6-13$ mutant lines. The findings of genetic diversity analysis through SSR markers RM32, RM202, RM351 and RM510 for $\mathrm{N}_{10} / 300 / \mathrm{P}-2(1)-3-5, \mathrm{~N}_{1} / 350 / \mathrm{P}-2-2-6$ and $\mathrm{N}_{1} / 250 / \mathrm{P}-6-2-7$ lines appeared to resemble to that of control (BRRI dhan56) from the UPGMA dendrogram. Based on morphological, molecular characteristics and UPGMA dendrogram study, mutant lines $\mathrm{N}_{10} / 300 / \mathrm{P}-2(1)-3-5$ and $\mathrm{N}_{1} / 250 / \mathrm{P}-6-2-7$ lines appeared superior as genetic material for developing better drought tolerant rice varieties.
\end{abstract}

Key words: NERICA, mutant lines, drought tolerance

Progressive Agriculturists. All rights reserve

*Corresponding Author: abir062003@gmail.com

\section{Introduction}

The NERICA (New Rice for Africa) rice variety was developed at the West Africa Rice Development Association (WARDA). In the early 1990s, a team of rice breeders led by Dr. Monty Patrick Jones at the main M'be research centre of WARDA in Bouak's, Côte d' Ivoire, developed stable and fertile progeny from crosses between Asian rice, O. sativa L. and African rice O. glaberrima Steud.(Jones et al., 1997b; Jones et al., 1997a). NERICA is a new drought tolerant rice variety which was introduced in Bangladesh from Uganda in 2009. However, the field performance of NERICA was not encouraging (a report published on 17 August 2014 Dhakatribune). Though its cause of low productivity in Bangladesh is still unrevealed, the farmers found low tiller number, weak and fragile stem could be the important morphological characters that compromised the yield (reported in a discussion meeting organized by UBINIG, 28 September 2012). Moreover, the scientists in the discussion meeting assumed that the low productivity could be due to climatic change and soil variation compared to its 
origin. For this reason, variations for yield contributing characters are needed to have the opportunity for improving these NERICA varieties for Bangladesh.

${ }^{1}$ MS Student, ${ }^{2}$ Associate Professor, Department of Biochemistry and Molecular Biology, ${ }^{4}$ Associate Professor, Department of Genetics and Plant Breeding, Bangladesh Agricultural University, Mymensingh, ${ }^{3}$ Senior Scientific Officer, Plant Breeding Division, ${ }^{5}$ Scientific Officer, Bangladesh Institute of Nuclear Agriculture, Mymensingh, Banghadesh.

Natural variations for yield contributing characters for NERICA varieties are not available in Bangladesh. However, variations can be created for those traits through mutation. Gamma $(\gamma)$ rays are physical mutagen and proven to be useful method for introducing new trait variations that may result in crop improvement (Babaei et al., 2010). Once induced, these variations can be used to develop suitable NERICA varieties for Bangladesh through conventional plant breeding approaches.

The experiment was undertaken to select the superior mutant lines for drought tolerance based on the study of morphological traits, followed by the genetic diversity analysis through the simple sequence repeat (SSR) markers.

\section{Materials and Methods}

\section{Plant materials}

The experiment was carried out with 18 rice germplasms in which promising 13 mutant lines of NERICA. BRRI dhan56 was used as control genotype.

\section{Mutant line production}

The seeds of NERICA were treated with physical (250, 300 and 350 Gamma-rays, unit is roentgen, R) mutagens and were grown as $\mathrm{M}_{1}$ generation. Populations were grown as advanced. Finally, 13 NERICA mutant lines were selected from $M_{4}$ to $M_{5}$ generations for this experiment.

\section{Plant culture}

The pot experiment was conducted during 2013-2014 in Boro season at the field laboratory of Bangladesh Institute of Nuclear Agriculture (BINA).

\section{Imposition of Drought}

For imposition of water stress 'soil $\mathrm{pH}$ and moisture tester' model DM-15 (made by Takemura Electric Works, Ltd. Tokyo, Japan) was used to determine the moisture level of soil. After 60 days of sowing when sufficient tiller was noticed, DM-15 was used and moisture level was recorded (scale range 1-8). For rice proper moisture scale is 3-5 (DM-15). After four days of water stress another reading was taken and it was in scale of DM-15 less than 2. Restricted amount of water was added to impose water stress. For stress plant $1000 \mathrm{ml}$ of fresh water was added at 96 hours interval for having moisture scale reading ranged as 1.5 to 2 (DM-15). Again for control, $2000 \mathrm{ml}$ of fresh water was added with same interval to maintain normal moisture level with DM-15 as 3 to 5 reading. During rainy days the pots were kept under plastic paper shade to avoid rainwater.

\section{Traits considered}

Data on days to 50 percent flowering, plant height, total number of tillers hill ${ }^{-1}$, panicle length and 100seed weight were recorded as follows from the trials conducted under two different hydrological conditions.

\section{DNA Extraction and quantification}

DNA extraction was done by the modified Cetyl Trimethyl Ammonium Bromide (CTAB) mini-prep method (IRRI, 1997). DNA samples were evaluated both quantitatively and qualitatively using spectrophotometer and $\lambda$ (lamda) DNA (concentration marker) respectively (Matin et al. 2012).

\section{Selection of SSR marker}

Based on previous references (Deshmukh, 2012 and Sonia, 2013) five SSR markers namely RM510, RM351, RM215, RM202, and RM32 were taken in this research work to screen on a sub sample of one randomly chosen individual from 18 rice genotypes to evaluate their suitability for amplifying DNA 
sequences, which could be accurately scored (Sonia, 2013). Out of 5 primers, 4 primers (RM510, RM351, RM202 and RM32) showed clear polymorphism which was used in selection of the rice lines for early maturing drought tolerance.

\begin{tabular}{cll}
\hline Primer name & Sequence (5' to 3' $^{\prime}$ References \\
\hline RM510 & Fwd: CGGATTAGTTCTCGCC & Sonia, 2013 \\
& Rev:TGAGGACGACGAGCAGATTC & \\
RM351 & Fwd:CCATCCTCCACCGCCTCTCG & Sonia, 2013 \\
& Rev:TGGAGGAAGGAAAGGGGACG & \\
RM202 & Fwd:CAGATTGGAGATGAAGTCCTCC & Deshmukh, 2012 \\
& Rev:CCAGCAAGCATGTCAATGTA & \\
RM32 & Fwd:AGTCTACGTGGTGTACACGTG & Deshmukh, 2012 \\
& Rev:TGCGGCCTGCCGTTTGTGGAG & \\
RM215 & Fwd:CAAAATGGAGCAGCAAGAGC & Sonia, 2013 \\
& Rev:TGAGCACCTCCTTCTCTGTAG & \\
\hline
\end{tabular}

\section{PCR and Gel electrophoresis}

The PCR cocktail was prepared and 25 bp ladder was used and then placed in the PCR tubes an $\mathrm{d}$ run in the DNA thermal cycler according to Matin et al. 2012. After completion of electrophoresis the gel was soaked in ethidium bromide $(10 \mathrm{ml})$ solution for 20-25 minutes then placed on high performance ultraviolet light box (UV transluminator) for checking the DNA bands and photographed using a Gel Documentary System of Biometra Company.

\section{SSR data analysis}

For SSR Data Analysis the size (in nucleotide base pairs) of the amplified band for each microsatellite marker was determined based on its migration relative to a molecular weight size marker (25 bp DNA Ladder) with the help of Alpha Ease FC 5.0 software. The summary statistics including the number of alleles per locus, major allele frequency, gene diversity and Polymorphism Information Content (PIC) values were determined using POWER MARKER version 3.23 (Liu and Muse, 2005), a genetic analysis software. The 18 lines were clustered based on the matrix of genetic similarities using the Unweighted Pair Group Method with arithmetic averages (UPGMA) the cluster analysis and dendrogram construction were performed with NTSYS-PC (version 2.1).

\section{Results}

One of the objectives of this experiment was to determine the phenotypic performance of 18 rice genotypes for drought tolerance. The lists of estimated characters and the mean performances of the 18 rice genotypes for the characters are shown in Table 1 and discussed below.

\section{Days of 50\% flowering}

The average range of days of $50 \%$ flowering was 77 to 128 (days), with a mean value of $93.92 \pm 3.20$ days. For drought effect, days of $50 \%$ flowering of the most of plants was decreased compared to the control plant. $\mathrm{N}_{10} / 300 / \mathrm{P}-2(1)-3-5$ plant showed the lowest days of 50\% flowering in drought condition.

\section{Plant height}

The average range of plant height was 63.33 to $115.33 \mathrm{~cm}$, with a mean value of $88.01 \pm 1.68$ cm. $\mathrm{N}_{10} / 300 / \mathrm{P}-2(1)-3-5$ plant showed the lowest plant height during drought condition.

\section{Total number of tillers hill ${ }^{1}$}

In this study, the average number of tiller hill ${ }^{-1}$ ranged from 7.67 to 50.00 with a mean value of $18.33 \pm 1.55$. The highest number of tillers were recorded in plant $\mathrm{N}_{10} / 300 / \mathrm{P}-2(1)$-3-5 during drought condition.

\section{Panicle length}

The average range of panicle length in this study 
varied from 22.67 to $26.33 \mathrm{~cm}$ with the mean value of $24.69 \pm 0.18 \mathrm{~cm}$. The plant $\mathrm{N}_{10} / 300 / \mathrm{P}-2(1)-3$ 5, $\mathrm{N}_{1} / 250 / \mathrm{P}-6-2-7$ and $\mathrm{N}_{10} / 300 / \mathrm{p}-(2) 1-6-13$ showed highest panicle length among the treated lines.

\section{0 seed weight}

There was a significant difference in 100 seed weight among the lines depending on the size and shape of grains. The range of 100 seed weight was 1.88 to $2.09 \mathrm{~g}$ with a mean value of 1.96 \pm 0.01 g. The highest 100 seed weight was recorded in plant $\mathrm{N}_{10} / 300 / \mathrm{P}-2(1)-3-5$ among the treated lines. Considering all the traits, $\mathrm{N}_{10} / 300 / \mathrm{P}-$ 2(1)-3-5 and $\mathrm{N}_{1} / 250 / \mathrm{P}-6-2-7$ genotypes were the best among 13 NERICA mutant lines.

Table 1. Mean performance of 18 rice genotypes for different morphological traits over drought condition

\begin{tabular}{|c|c|c|c|c|c|c|c|c|c|c|}
\hline \multirow[t]{2}{*}{ Genotypes } & \multicolumn{2}{|c|}{$\begin{array}{l}\text { Days of } 50 \% \\
\text { flowering }\end{array}$} & \multicolumn{2}{|c|}{ Plant height (cm) } & \multicolumn{2}{|c|}{$\begin{array}{c}\text { Total number of tiller } \\
\text { hill-1 }^{-1}\end{array}$} & \multicolumn{2}{|c|}{ Length of panicle(cm) } & \multicolumn{2}{|c|}{100 seed wt. (g) } \\
\hline & Control & Treatment & Control & Treatment & Control & Treatment & Control & Treatment & Control & Treatment \\
\hline $\mathrm{N}_{10} / 300 / \mathrm{P}-2(1)-3-5$ & 800 & $77 r$ & $75.33 \mathrm{st}$ & $63.33 u$ & $50.00 \mathrm{a}$ & $43.67 \mathrm{~b}$ & $26.33 a$ & $26.33 a$ & $2.090 \mathrm{a}$ & $2.090 \mathrm{a}$ \\
\hline $\mathrm{N}_{4} / 250 / \mathrm{P}-1-10-11$ & $84 \mathrm{k}$ & $82 \mathrm{~m}$ & $84.67 \mathrm{mno}$ & $81.33 p$ & $18.33 \mathrm{hi}$ & $14.67 \mathrm{jk}$ & $26.00 \mathrm{ab}$ & $24.33 \mathrm{efg}$ & $1.970 \mathrm{bcd}$ & $1.900 \mathrm{fg}$ \\
\hline $\mathrm{N}_{1} / 350 / \mathrm{P}-1-10-2$ & $84 \mathrm{k}$ & $81 \mathrm{n}$ & $88.67 \mathrm{ijk}$ & $85.33 \mathrm{Imn}$ & $10.67 \mathrm{Imno}$ & 9.670 nopq & $25.33 \mathrm{bcd}$ & 25.00 cde & $1.970 \mathrm{cde}$ & $1.880 \mathrm{~g}$ \\
\hline $\mathrm{N}_{4} / 300 / \mathrm{P}-3(4)-10-9$ & $83 \mid$ & $81 n$ & $96.67 \mathrm{de}$ & $91.00 \mathrm{hi}$ & $11.67 \mathrm{Imn}$ & $10.33 \mathrm{mnop}$ & $24.33 \mathrm{efg}$ & $23.67 \mathrm{gh}$ & $1.900 \mathrm{fg}$ & 1.930 defg \\
\hline$N_{1} / 300 / P-8-3-3$ & $87 i$ & $82 \mathrm{~m}$ & $87.33 \mathrm{jklm}$ & 82.33 op & $14.33 \mathrm{jk}$ & $12.00 \mathrm{Im}$ & $24.00 \mathrm{fgh}$ & $22.67 \mathrm{i}$ & $1.970 \mathrm{bcd}$ & 1.950 cdef \\
\hline $\mathrm{N}_{10} / 300 / \mathrm{P}-2(1)-3-6$ & $85 \mathrm{j}$ & $84 \mathrm{k}$ & $101.0 \mathrm{C}$ & 94.67 ef & $15.00 \mathrm{j}$ & $12.67 \mathrm{kl}$ & $24.33 \mathrm{efg}$ & $24.33 \mathrm{efg}$ & $2.000 \mathrm{bc}$ & $1.900 \mathrm{fg}$ \\
\hline$N_{1} / 350 / P-2-2-6$ & $83 \mid$ & $79 p$ & $93.67 \mathrm{fg}$ & 90.00 hij & $17.67 \mathrm{hi}$ & $14.67 \mathrm{jk}$ & $24.00 \mathrm{fgh}$ & $23.33 \mathrm{hi}$ & $1.910 \mathrm{efg}$ & 1.970 bcde \\
\hline $\mathrm{N}_{10} / 300 / \mathrm{P}-2-3-5$ & $88 \mathrm{~h}$ & $84 \mathrm{k}$ & $94.00 \mathrm{f}$ & 85.00 Imno & $19.33 \mathrm{gh}$ & $14.67 \mathrm{jk}$ & $23.67 \mathrm{gh}$ & $23.67 \mathrm{gh}$ & $1.970 \mathrm{bcd}$ & 1.970 bcde \\
\hline $\mathrm{N}_{1} / 250 / \mathrm{P}-6-2-7$ & $81 \mathrm{n}$ & $78 q$ & $80.67 \mathrm{pq}$ & $73.00 \mathrm{t}$ & $28.67 \mathrm{c}$ & $24.67 d$ & $26.33 \mathrm{a}$ & $26.33 \mathrm{a}$ & $2.090 \mathrm{a}$ & $2.030 \mathrm{~b}$ \\
\hline $\mathrm{N}_{1} / 300 / P-9-4-11$ & $85 j$ & $81 n$ & $86.67 \mathrm{klm}$ & $81.00 \mathrm{pq}$ & $12.00 \mathrm{Im}$ & 10.33 mnop & $23.67 \mathrm{gh}$ & $23.67 \mathrm{gh}$ & $1.900 \mathrm{fg}$ & $1.940 \mathrm{cdefg}$ \\
\hline $\mathrm{N}_{10} / 300 / \mathrm{P}-2(1)-6-13$ & $81 n$ & $79 p$ & $81.67 p$ & $76.67 \mathrm{rs}$ & $27.67 \mathrm{c}$ & $24.33 d$ & $26.33 \mathrm{a}$ & $26.33 \mathrm{a}$ & $2.030 \mathrm{~b}$ & $1.990 \mathrm{bcd}$ \\
\hline $\mathrm{N}_{1} / 300 / \mathrm{P}-8-3-1$ & $87 i$ & $83 \mid$ & $98.67 \mathrm{~cd}$ & $92.00 \mathrm{fgh}$ & $19.33 \mathrm{gh}$ & $17.33 \mathrm{hi}$ & $25.67 a b c$ & 24.67 def & 1.950 cdef & 1.970 bcde \\
\hline $\mathrm{N}_{10} / 300 / \mathrm{P}-7-1$ & $82 \mathrm{~m}$ & $79 p$ & 83.00 nop & $78.67 \mathrm{qr}$ & $27.33 c$ & $23.67 \mathrm{~d}$ & $26.33 a$ & $25.67 a b c$ & $2.030 \mathrm{~b}$ & $1.990 \mathrm{bcd}$ \\
\hline BINA dhan8 & $123 d$ & $119 \mathrm{~g}$ & $91.33 \mathrm{gh}$ & $87.67 \mathrm{jkl}$ & $8.330 \mathrm{pq}$ & $7.670 q$ & 25.00 cde & $24.33 \mathrm{efg}$ & $1.970 \mathrm{bcd}$ & 1.910 efg \\
\hline BINA dhan10 & $127 \mathrm{~b}$ & $123 d$ & $86.00 \mathrm{klm}$ & 82.33 op & $24.67 \mathrm{~d}$ & $21.67 \mathrm{ef}$ & $23.33 \mathrm{hi}$ & $23.33 \mathrm{hi}$ & $1.990 \mathrm{bcd}$ & $1.900 \mathrm{fg}$ \\
\hline BINA dhan11 & $128 \mathrm{a}$ & $122 \mathrm{e}$ & $88.33 \mathrm{jk}$ & $84.67 \mathrm{mno}$ & $9.000 \mathrm{opq}$ & $8.670 \mathrm{opq}$ & $24.33 \mathrm{efg}$ & $23.67 \mathrm{gh}$ & 1.94 cdefg & 1.920 efg \\
\hline BINA dhan12 & $127 \mathrm{~b}$ & $121 f$ & $99.33 \mathrm{C}$ & $94.67 \mathrm{ef}$ & $23.33 \mathrm{de}$ & $21.00 \mathrm{fg}$ & $25.33 \mathrm{bcd}$ & 25.00 cde & 1.910 efg & 1.910 efg \\
\hline BRRI dhan56 & $127 \mathrm{~b}$ & $124 \mathrm{c}$ & $115.3 \mathrm{a}$ & $112.3 \mathrm{~b}$ & $16.33 \mathrm{ij}$ & $14.67 \mathrm{jk}$ & $24.00 \mathrm{fgh}$ & $24.00 \mathrm{fgh}$ & $1.970 \mathrm{bcd}$ & $1.950 \mathrm{cdef}$ \\
\hline LSD $_{0.05}$ & \multicolumn{2}{|c|}{1.71} & \multicolumn{2}{|c|}{2.44} & \multicolumn{2}{|c|}{1.89} & \multicolumn{2}{|c|}{$\frac{1}{0.632}$} & \multicolumn{2}{|c|}{$\begin{array}{l}1 \\
0.051\end{array}$} \\
\hline Level of significance & \multicolumn{2}{|r|}{ 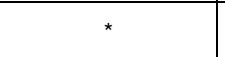 } & & \multicolumn{2}{|c|}{ ** } & & \multicolumn{2}{|c|}{ ** } \\
\hline CV (\%) & \multicolumn{2}{|c|}{1.12} & \multicolumn{2}{|c|}{1.70} & \multicolumn{2}{|c|}{6.36} & \multicolumn{2}{|c|}{1.57} & \multicolumn{2}{|c|}{1.70} \\
\hline
\end{tabular}

\section{SSR Data Analysis}

In this study 18 rice genotypes were analyzed using 4 SSR markers (RM202, RM351, RM32 and RM510) and their SSR profile picture are given in Fig.1 (AD). A total of 33 alleles were detected among 18 rice genotypes. The average number of allele per locus was 8.25 with a range of 7 (RM202 and RM510) to 10 (RM32). According to Nei's dendrogram (1983) the highest level of genetic diversity (0.8580) was observed in loci RM351 and RM32 and the lowest level of genetic diversity (0.7654) was observed in loci RM202 with a mean diversity of 0.8241 . The polymorphism information content (PIC) values in this study varied from $0.7361(\mathrm{RM} 202)$ to 0.8431
(RM32) with an average of 0.8028. A dendrogram constructed based on Nei's, (1983) genetic distance using UPGMA (Unweighted Pair Group Method of Arithmetic Means) indicated segregation of 18 rice lines into two main groups. N1/350/P-2-2-6, N1/250/P-6-2-7, N10/300/P-2(1)-3-5, BRRI dhan56 genotypes are in the same cluster and showed minimum genetic distance.

The present study addressed the utilization of SSR markers, to determine genetic diversity and relationship among mutant lines at molecular level. The genetic diversity determined in this study will help in the selection of mutant lines. On the basis of this 
experiment plant number $\mathrm{N}_{1} / 350 / \mathrm{P}-2-2-6, \mathrm{~N}_{1} / 250 / \mathrm{P}-$ 6-2-7 and $\mathrm{N}_{10} / 300 / \mathrm{P}-2(1)-3-5$ could be selected as

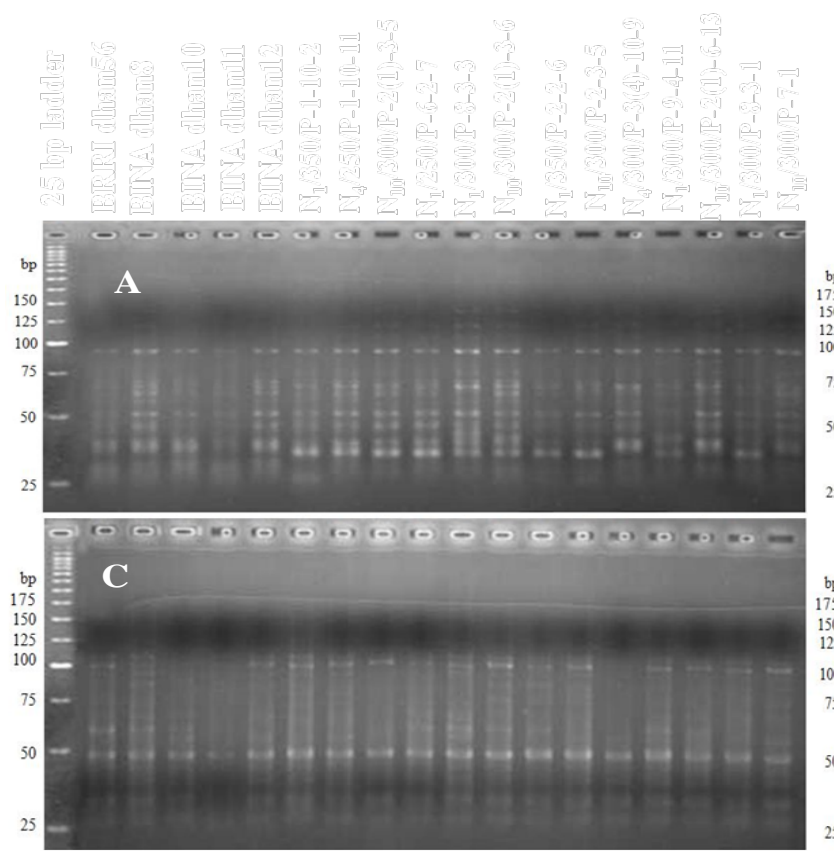

Figure 1: SSR profile of 18 rice genotypes for RM32(A), RM202(B), RM351(C) and RM510(D) desired drought tolerant early maturing mutant NERICA lines.

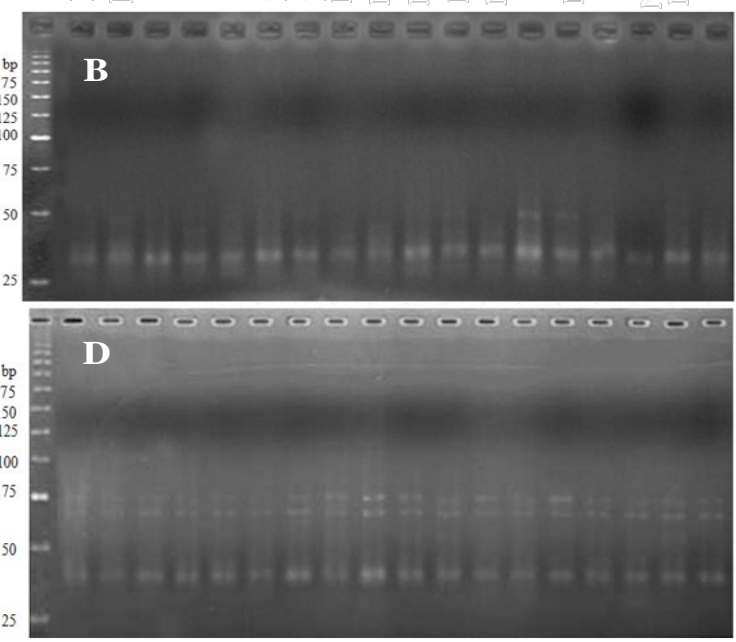

Figure 2. UPGMA dendrogram based on Nei's (1983) genetic distance, summarizing data on differentiation between 18 rice genotypes, according to SSR analysis.

The present study addressed the utilization of SSR markers, to determine genetic diversity and relationship among mutant lines at molecular level. The genetic diversity determined in this study will help in the selection of mutant lines. On the basis of this experiment plant number $\mathrm{N}_{1} / 350 / \mathrm{P}-2-2-6, \mathrm{~N}_{1} / 250 / \mathrm{P}-$ 6-2-7 and $\mathrm{N}_{10} / 300 / \mathrm{P}-2(1)-3-5$ could be selected as desired drought tolerant early maturing mutant NERICA lines.

\section{Discussion}

It was observed that genotypic variations were highly significant for all the characters. Due to the imposition of drought $\mathrm{N}_{10} / 300 / \mathrm{P}-2(1)-3-5$ took only 99 days to mature. Flowering time is an important trait related to drought adaptation, where a short life cycle can lead to drought escape (Araus et al., 2002). $\mathrm{N}_{10} / 300 / \mathrm{P}-2(1)-3-5$ plant at drought condition showed the lowest plant height which is desirable. Correlations observed between plant height and maturity in different environments for 57 introgression lines developed in IR64 background in IRRI's molecular breeding program (Lafitte et al. 2007). In drought condition $\mathrm{N}_{10} / 300 / \mathrm{P}-2(1)-3-5$ showed maximum number of tillers which was in average 43.67. Miller et al. (1991) reported that the number of fertile tillers is the most important yield 
components, which includes $86 \%$ of yield changes in drought stress. The plant $\mathrm{N}_{10} / 300 / \mathrm{P}-2(1)-3-$ 5, $\mathrm{N}_{1} / 250 / \mathrm{P}-6-2-7, \mathrm{~N}_{10} / 300 / \mathrm{p}-(2) 1-6-13$ at drought stress and $\mathrm{N}_{10} / 300 / \mathrm{P}-2(1)-3-5, \quad \mathrm{~N}_{1} / 250 / \mathrm{P}-6-2-7$, $\mathrm{N}_{10} / 300 / \mathrm{p}-(2) 1-6-13$ and $\mathrm{N}_{10} / 300 / \mathrm{p}-7-1$ at control condition showed highest panicle length and $\mathrm{N}_{1} / 300 / \mathrm{p}-8-3-3$ at drought condition showed lowest panicle length. Mirza et al. (1992) found panicle length was positively correlated with number of grains per panicle in drought stress. The highest 100 seed weight was recorded in plant $\mathrm{N}_{10} / 300 / \mathrm{P}-2(1)$ 3-5 at control condition. Weight of 1000 seed is one of the major yield components which are a stable property of cultivars due to higher genetic stability than other yield components. It is not affected by environmental factors (Rafiee, 2008). The average number of allele per locus was 8.25 with a range of 7 (RM202 and 510) to 10 (RM32). Jain et al. (2004) got similar number of allele per locus ranging from 3 to as high as 22 with an average of 7 alleles per locus. The PIC values in this study varied from 0.7361 (RM202) to 0.8431 (RM32) with an average of 0.8028. Jain et al. (2004), reported on PIC values ranged from 0.24 to 0.92 with an average of 0.61 .

\section{Conclusion}

Considering important morphological characters and from UPGMA dendrogram it is concluded that $\quad \mathrm{N}_{10} / 300 / \mathrm{P}-2(1)-3-5$ and $\mathrm{N}_{1} / 250 / \mathrm{P}-6-2-$ 7 genotypes were the best among 13 NERICA mutant lines. These genotypes can be used for field trial for suggesting new drought tolerant early maturing genetic materials.

\section{References}

Araus JL, Royo C (2002). Plant breeding and water relations in C3 cereals: what should we breed for? Annals of Botany, 89: 925-940.

Babaei A, Hashemi H (2010). Radio sensitivity studies of morpho-physiological characteristics in some Iranian rice varieties (Oryza sativa L.) in $\mathrm{M}_{1}$ generation. African Journal of Agricultural Research, 5(16): 2124-2130.
Deshmukh VV (2012). Genome wide association mapping of drought resistance traits in rice (Oryza sativa L.). MS thesis. Department of Plant Biotechnology. Tamil Nadu Agricultural University. Coimbatore. Pp. 50-93.

Dhakatribune (2014). A news report published on 17 August2014 (http://www.dhakatribune.com /bangladesh/2014/aug/17/govt-promotingafrican-nerica-rice-variety-despite-negativeresult)

IRRI (1997). International Rice Research Institute. Annual Report for 1997. Los Banos, Laguna, Philippines. pp.308.

Jain S, Jain RK, McCouch SR (2004). Genetic analysis of Indian aromatic and quality rice (Oryza sativa L.) germplasm using panels of fluorescently labeled microsatellite markers. Theory of Applied Genetics, 109: 965-977.

Jones CJ, Edwards KJ (1997). A Reproducibility testing of RAPD and SSR markers in plants by a network of European laboratories. Molecular Breeding, 3: 381-390.

Jones N, Oughum H, Thomas H (1997). Genome mapping, molecular markers and markerassisted selection in crop plants. New Phytologist, 137: 165-177.

Lafitte HR, Yongsheng G, Yan S, Li ZK (2007). Whole plant responses, key processes and adaptation to drought stress: the case of rice. Journal of Experimental Botany, 58 (2): 169-175.

Liu K, Muse SV (2005). Power Marker: Integrated analysis environment for genetic marker data. Bioinformatics, 21, 2128-2129.

Matin S, Ashrafuzzaman M, Islam MM , Sikdar SU, Zobayer N (2012). Molecular marker based (SSR) genetic diversity analysis in deep water rice germplasms of Bangladesh. International Journal of Biosciences, 10(2): 64-72.

Miller BC, Hill JE, Roberts SR (1991). Plant population effects on growth and in water seeded rice. Agronomical Journal, 83: 291297.

Mirza MJ, Faiz FA, Majid A (1992). Correlation studies and path analysis of plant height, 
Hasan et al. (2015), Progressive Agriculture 26: 15-21

yield and yield components in rice (Oryza sativa L.). Sarhad Journal of Agriculture, 8(6): 647-653.

Nei M (1983). Analysis of gene diversity in subdivided populations. Proceedings of the National Academy of Sciences, USA, 70 3321-3323.

Rafiee M (2008). Effects of planting date on yield of some cultivars in Khorramabad condition. Journal of Agricultural Research, 37: 251263.
Sonia N (2013). Morphological Characterization and Genetic Diversity Analysis of Drought Tolerant NERICA-4 Mutant Lines Using SSR and RAPD Markers. MS thesis. Department of Biotechnology, Bangladesh Agricultural University, Mymensingh, pp 523.

UBINIG (2012). A Discussion Meeting on "NERICA Rice and Bt Brinjal" Organized by UBINIG on 17 September 2012 (http://ubinig.org/index.php/home/showAert icle/39 